\title{
Immigration policies in Italy: their impact on the lives of first-generation Moroccan and Egyptian migrants
}

\author{
ANGELA PAPARUSSO \\ Sapienza University of Rome, Department Statistical Sciences, \\ Viale Regina Elena 295-00161, Rome, Italy
}

TINEKE FOKKEMA

Netherlands Interdisciplinary Demographic Institute (NIDI-KNAW), University of Groningen, P.O Box 11650, 2502 AR The Hague, The Netherlands

\section{ELENA AMBROSETTI}

Sapienza University of Rome, Department of Methods and Models for Economics, Territory and Finance, Via del Castro Laurenziano, 9-00161, Rome, Italy

\begin{abstract}
This paper analyzes the impact of Italian immigration policies on migrants' lives. Policies and changes in policies can affect migrants' capabilities to stabilize themselves in the host country, in terms of legal residence and secure labor conditions, as well as their chances of becoming part of the host society. We argue that, together with border controls, these are crucial ways through which immigration policies may have the postulated effects on the lives of migrants. We use data from 59 in-depth interviews conducted with first-generation Moroccan and Egyptian migrants living in two Italian cities, Turin and Rome, in the period 2011-2013. The results show that Italian immigration policies do not successfully control migration inflow, but effectively hinder the stability of migrants' legal status and the status transition from temporary residence to permanent residence and subsequent Italian citizenship. In this way, Italian immigration policies largely affect migrants' capabilities to be part of the host country; this gets in the way of integration, social cohesion and future migration projects.
\end{abstract}

KEY WORDS - policy effectiveness, migrant status, qualitative research 


\section{Introduction}

Although migration policies cover both emigration and immigration, the debate and government agenda are more focused on the latter (de Haas and Vezzoli 2011). Especially in southern Europe, immigration policies tend to privilege issues dealing with the entry of migrants (e.g. legal and illegal entries, regularization of illegal migrants and family reunification) over aspects of integration (Pastore 2004; Solé 2004). These imbalances in both debate and policy action are mainly due to receiving countries' continuous efforts to control immigration, stop unauthorized entries and determine the number and the composition of migrants.

Although policies contribute to define the migration outcomes, changing the routes and channels through which people migrate, the factors determining and nurturing migration are too complex and deep-rooted in both origin and destination areas to achieve considerable immigration reduction, making policies marginal and inefficient (Castles 2004a; 2004b; Cornelius 2005; Vogel 2000). In addition, immigration policies are usually used as short-term measures for electoral purposes or to achieve contingent objectives (Czaika and de Haas 2013), while migrations are long-term and "self-sustaining processes" (Castles 2004b: 222). Immigration policies are not free of paradox and ambiguity either (Geddes 2008). For instance, policymakers often have to conciliate widespread sentiments of anxiety and fear against immigrants with economic needs such as the involvement of foreigners in some sectors of the national labor market. In the same way, while governments use harsh instruments to combat illegal entries, they leave the back door of the informal labor market open to immigrants.

Having said that, what immigration policies are undoubtedly able to do is "to perfectly define the conditions of migration" (Cornelius and Rosenblum 2005: 112). In particular, immigration policies define the status of migrants, create categories according to which migrants are classified (legal and illegal, temporary and permanent, labor, family and humanitarian migrants) and determine the rights they can benefit from in each category. For instance, immigration policies establish the precise circumstances and requirements to enter and remain permanently in the labor market of the receiving country, to have access to family reunification rights, to obtain citizenship in the country of residence and even to leave the country without losing social and economic benefits. Immigration policies also determine the "status mobility" (Schuster 2005: 762), i.e. the possibility and the conditions under which migrants can move from one category to another, improving or worsening their status. Policies and changes in policies can affect migrants' capabilities to stabilize themselves in the host country, in terms of legal residence and secure labor conditions (Morris 2001), as well as their chances of becoming part of the host society.

We argue that, together with border controls, these are crucial ways through which immigration policies may have the postulated effects on the lives of migrants. However, sometimes the strictness of policies and migrants' perception of these as unfair lead migrants to circumvent rules, overcoming the existing barriers within categories, 
statuses and sets of rights. This reveals the weakness of some policy decisions and, more generally, the tendency of immigration policies to have unexpected and unintended consequences (e.g. Joppke 1998; Ruhs 2008). The ensemble of the intended and expected effects, the unexpected and unintended consequences, and migrants' perception of immigration policies constitutes what we define "the impact" of immigration policies on the lives of migrants.

The aim of this paper is to examine, through 59 in-depth interviews carried out with first-generation Egyptian and Moroccan migrants living in two Italian cities, Turin and Rome, the impact of Italian immigration policies on migrants' lives. Data will be used from the project “Transmediterraneans: North African Communities in Piedmont, between continuity and change", conducted by Fieri, together with Sapienza University of Rome from September 2011 to January 2013. A sample of respectively 33 and 26 in-depth face-to-face interviews with first-generation Moroccans and Egyptians, aged 25-70 living in Turin and Rome are analyzed.

The paper is structured as follows: section 2 presents a historical overview of the immigration and immigration policies of Italy. In section 3 data and methods are described, followed by the presentation of the main results of our analysis in section 4 . The paper will end with the discussion of the main findings. For the description of Italian immigration policies we constructed a database, collecting original legal texts on immigration in Italy starting from 1912. We focused on admission and citizenship (naturalization) policies, the latter being a little-explored research topic in Italy despite the growing interest by public opinion in recent years. Integration policies strictu senso (language courses for migrants, cultural mediators, policies against discrimination; Saraceno et al. 2013) are not contemplated. Given the complexity and large number of changes in the laws governing immigration policies and the lack of a condensed summary of these changes, we have made a detailed historical scheme of Italian immigration policies, general and separately by type of policy; this scheme is available on the Journal website. As the focus of our analysis are Moroccans and Egyptians living in Italy, our attention lies on those laws that could have an impact on non-EU immigrants.

\section{Immigration and immigration policies in Italy}

Italy turned into an immigration country after the 1973 international oil crisis, when the economic downturn induced the governments of northern European countries to stop recruiting workers from abroad. Today Italy is one of the major destinations for immigrants in Europe, despite the recent economic crisis (Pastore and Villosio 2011). The foreign resident population has increased over the years, from 648,935 individuals in 1992 to 1,340,655 in 2000, reaching 4.9 million in 2014 (Istat online database); this represents 8 percent of the total population. These figures do not take into 
account undocumented immigrants, whose numbers are difficult to estimate properly, although the ISMU Foundation suggests around 544,000 undocumented individuals as of 1 January 2010 (ISMU 2011).

The vast majority of the first migrants to Italy came from North Africa (e.g. Morocco, Tunisia and Egypt). More recently, Italy has witnessed a strong inflow of migrants from Eastern European countries (e.g. Romania and Albania) and, to a lesser extent, East Asian countries (China and the Philippines), although arrivals from North Africa remain important. In particular, with 454,773 and 96,008 residents respectively (Istat online database, 2013), Moroccans and Egyptians form the largest North-African communities residing in Italy who, given their long migration history, are now experiencing the aging of some of their first-generation members and the growing-up of the second generations (Cingolani and Ricucci 2013).

While Italy made the transition from an emigration to an immigration country in mid-1970s, acceptance of the existence of the phenomenon of immigration was late: the first immigration law was introduced as late as 1986 (Einaudi 2007; Zincone 1998). Before that, laws on immigration were extremely fragmentary (Nascimbene 1988) and the entry and stay of foreigners were regulated by a public security act from 1931 together with a long series of administrative circulars of the Ministries of Labor, the Interior and Foreign Affairs. ${ }^{1}$ The need for comprehensive legislation on immigration became urgent in the early 1980s, when Italy faced a large number of foreigner residents, and due to the signature in 1975 and the ratification by the Italian government in 1981 of the ILO Convention to provide proper legislation for migrant workers (Colombo and Sciortino 2004a). ${ }^{2}$ The first immigration law, known as the Foschi Law, addressed non-EU workers only and aimed to prevent illegal immigration (Zincone 1998: 49); it defined and introduced for the first time family reunion as well as a regularization. With regard to family reunification, relatives who could enter and obtain legal status in Italy through the Foschi Law are: spouse, minor children, adult children who cannot live independently for health reasons (100\% invalidity), and parents who lack adequate family support in the country of origin (i.e. no children left in the country of birth or persons aged 65 or older who do have children in the country of origin but these children have severe health problems and therefore cannot take care of their parents). At this point, family reunification became one of the major entry channels in Italy (Cvajner and Sciortino 2010; Reyneri 2001). In terms of regularization, 120,000 irregular migrants benefited from the amnesty (Einaudi 2007; Reyneri 1998). The aim of the Foschi Law was considered restrictive, because to hire a non-EU worker an employer had to prove that there were no Italian or EU workers that could fill that job (Zincone and Caponio 2004). However, as Colombo and Sciortino

\footnotetext{
${ }^{1}$ Circulars should be considered as texts issued by Ministries; their main aim is to explain how to implement a law or as internal norms (Mezger and Gonzalez-Ferrer 2013; Nascimbene 1988). These legal texts are often internal ministerial documents, therefore not accessible to the public.

${ }^{2}$ According to the Convention, receiving countries should promote social and economic integration of migrant workers through basic human and work rights (social benefits, strikes, association, membership in labor associations) and family reunification.
} 
(2004a) pointed out, Italian borders were left open for foreigners who could easily enter the country with a tourist visa and work in the black market.

The persistent inflow of immigrants, especially after the fall of the iron curtain, as well as the imminent ratification of the Schengen Treaty (1993), pushed Italian legislators to introduce a new law regulating immigration in 1990. The Martelli Law was the first organic law on immigration and, in contrast to the Foschi Law, covered not only labor migration but all kinds of migration motives. The main aim of this law was to restrict the entry of foreigners to Italy through the introduction of a compulsory entry visa and the enforcement of border controls and expulsion measures. The law also aimed at ameliorating the conditions of migrants already present in the Italian territory, hence all non-EU immigrants present before 31 December 1989, whether they had a regular labor contract or not, could apply for regularization. The conditions of the regularizations were not much different from the earlier amnesty of 1986 and resulted in about 218,000 immigrants obtaining a legal status (Reyneri 1998). The Martelli Law was an example of such a contradiction between public rhetoric and policy action, leading to a huge increase in the number of undocumented immigrants and negative sentiments and attitudes towards immigrants.

In 1995 another reform to the existing legislation was introduced: the Dini Decree. As most of the articles of the Decree were considered to be against the Italian Constitution, the reform was never applied, with the exception of a new amnesty and new rules for family reunification. The amnesty initially applied to dependent employees and, for the first time, family migrants only. The Decree covered the possibility of regularization of irregular workers as well as non-workers. Like in the past regularizations, migrants had to show their passport and proof of Italian residence at the moment of the amnesty. They also had to show having proper housing, a minimum income and a job offer or proof of work - even illegally - dating back at least four months before the introduction of the amnesty; for job-seekers, the possibility of getting regularized was no longer an option. Despite the restrictiveness of the regularization rules, over 250,000 immigrants were regularized under the Dini Decree. These figures show that the irregular presence of foreigners in Italy had increased since the early 1990s. Since 1995, EU citizens requesting family reunification must show having proper housing and an income at least equaling the minimum welfare check.

In the second half of the 1990s, Italy had not yet realized a comprehensive legislation on migration. The need for a reform of the previous laws was quite strong, for several reasons. First, Italy became a full member of the Schengen Agreement in 1990, so it had to reconcile its migration control policies with those implemented by other states; second, the Italian government had to reassure the public opinion about the state's ability to control migration effectively; and finally, it had to show to the public opinion and to the European partners that it was able to fight against illegal immigration. After a long process that started in the mid-1990s, in 1998 the Single Act of Immigration law was approved, better known as the Turco-Napolitano Law. The Act was based on four pillars (Zincone and Caponio 2004: 
4): 1. Prevention and fight of illegal entries: besides the immediate expulsion of illegal migrants, the Act introduced Centers of Temporary Permanence to detain illegal migrants waiting for expulsion; 2. Regulation of new arrivals of foreign workers through annual worker quotas established each year by the Ministry of Labor, and the introduction of a special settlement permit, the 'sponsor system', that allowed foreigners to enter Italy to look for a job if they were sponsored by an Italian or a foreigner legally residing in Italy who could provide the financial backing; 3 . Promoting the integration of migrants already residing in Italy through the creation of a 'National Integration Fund' that was dedicated to finance multicultural activities and the introduction of the permanent residence permit for those migrants with five years of residence in Italy; 4. Granting basic human rights, such as basic health care, to irregular migrants. The Single Act also included a new amnesty for non-EU illegal workers present in Italy on 27 March 1998. According to Interior Ministry data, 217,000 immigrants were regularized.

International migration, particularly the commitment to fight against illegal migration, was at the core of the electoral campaign of 2000-2001, especially for center-right-wing political parties that won the election. As promised during the electoral campaign, the center-right-wing government coalition did reform the Single Act of 1998 by introducing the Bossi-Fini Law in 2002. More specifically, the law modified the first two pillars of the Act, further restricting residence permits and illegal entries. To discourage permanent settlement of migrants, a series of measures were introduced: abolition of the sponsor system, shortening of validity period of the residence permit, and linking the validity of permit of stay to a job contract ("residence contract"). A more repressive policy toward illegal migrants included better enforcement of compulsory repatriation, more systematic police controls that included patrol of the Italian coastlines, and detention of overstayers - people who remain illegally in Italy after expiration of their permit (612 months for second infractions without a residence permit, and 1-4 years for third-time violations). An amnesty was also established by the Bossi-Fini Law for those non-EU foreigners who had been working irregularly in Italy for at least three months before the law became effective (July 2002). It was the biggest amnesty ever given in Europe: 646,000 immigrants were regularized under this law (Italian Ministry of Interior). The main difference with past amnesties is that the entire procedure was delegated to employers.

In the last 11 years, few changes to the migration regulations have been implemented: measures to fight against illegal migration, amnesties for irregular migrants present in the Italian territory, and execution of EU directives that implied changes to the existing regulation. The Legislative Decree 241/2004 "Urgent measures on immigration" stated that illegal migrants who did not leave the Italian territory after a judgment of expulsion should be jailed for a period of 1-4 years. A new amnesty was introduced in 2009: contrary to past regularizations, it applied to domestic care workers only. The reason behind this amnesty was that, despite the economic crisis, the domestic workers sector continued to grow and therefore the demand for foreign workforce too (Ambrosini 2013). To be eligible for regularization one had to 
be employed at least three months for a family and the employer had to show proof of having an annual income of at least 20,000 euros. Around 222,000 immigrants were regularized (Italian Ministry of Interior). Decree 109/2012 introduced an amnesty addressed to irregular non-EU workers (particularly full-time workers and domestic workers working at least 20 hours per week): it was the employer who should provide all the documents. The new element of this amnesty was that 1,000 euros per worker should be paid by the employer. According to available data, so far 23,000 immigrants have been regularized (Italian Ministry of Interior). Legislative Decree no. 5 of 8 January 2007 executed a CEE Directive about family reunification which is granted according to the effectiveness of family ties by showing official documents (i.e. marriage license, birth certificate). Those requesting family reunification should have a permit of stay (work, asylum, study, religion, family) for at least one year.

The acquisition of citizenship by birth (jus sanguinis) and by residence (jus soli) was initially regulated by Law 555/1912. The conditions were very restrictive: citizenship was only granted to a child of an Italian man and specific conditions to the child of an Italian woman. Law 123/1983 introduced to Italian legislation the acquisition of citizenship by marriage and reformed the acquisition of citizenship by birth, giving the right of Italian citizenship from birth to a child of either an Italian man or an Italian woman. Acquisition of Italian citizenship was further reformed by Law 91/1992. Citizenship could be acquired by birth or by residence or family formation under specific conditions. The rights to citizenship have been further restricted in recent years, especially by the centre-right coalition: citizenship by marriage was reformed in 2009 (Law 94 of 15 June), prolonging the needed period of residence in Italy from six months to two years from the date of the marriage. Several attempts asking for acquisition of citizenship by birth for secondgeneration migrants have been made by both political parties and civil society. As a first result, art. 33 of Decree 69/2013 simplified the citizenship acquisition procedure for foreigners born in Italy. All of this notwithstanding, up to now second-generation migrants are not granted citizenship by birth.

In sum, from this historical overview it becomes apparent that immigration policies in Italy have witnessed many changes and modifications with the aim of complying with EU reforms, combating illegal entry, restraining the number of regular migrants and discouraging their permanent settlement. The result has been an increase in restrictiveness over time, regardless of the political color of government coalitions in power. Still, Italian migration policies have been less rigid than those of other European countries, as several non-restrictive measures were introduced too. Because of the need to meet the vast and increasing demand for cheap labor (e.g. the need for foreign female caretakers of Italian elderly and children - badanti - and the demand for male workers in the agricultural and catering sectors), an annual quota system for the admission of foreigners for work-related reasons was enacted several times (Ambrosini 2013; Pastore 2004) and irregular migrants have been legalized through a series of amnesties. In addition, although the conditions for family reunification in Italy have become more restrictive over time, compared to other 
European countries they are generous. Family members thus operate as one of the most important social networks used by migrants to enter and permanently settle in the country (Cvajner and Sciortino 2010). Data provided by Eurostat reveal that out of a total of 3,943,269 permits delivered in Italy at the end of 2014, 2,030,432 were for family reasons and 1,720,354 for remunerated activities. As far as citizenship is concerned, Italian policy is not very benevolent toward its migrants though. Italian citizenship policy is considered one of the most exigent in terms of residence requirements and one of the most discretional in Europe (Sciortino 2002). The Italian naturalization rate, the ratio between the yearly number of naturalizations and the number of foreign residents in the country, was about $2.3 \%$ in $2014-$ one of the lowest rates in Europe (Eurostat online database).

Given the research aim and above-sketched increasing restrictiveness of Italian immigration policies, our study was led by the following research questions: Do the restrictive changes in Italian immigration policies have the postulated effects, by increasing the complexity of requirements migrants have to meet in order to obtain and benefit from a certain legal status, particularly to become Italian citizens? How fairly do migrants perceive the increasing restrictiveness of Italian immigration policies? What are the unintended effects of the restrictive changes in Italian immigration policies? And in which ways do migrants try to circumvent the enhanced entry and residence rules?

\section{Data and methods}

Data stems from the project "Transmediterraneans. North African Communities in Piedmont, between continuity and change", carried out from September 2011 to January 2013 by FIERI, together with Sapienza University of Rome. Respectively, 26 and 33 qualitative face-to-face interviews were conducted with first-generation Moroccan and Egyptian migrants living in the cities of Turin and Rome. Interviews were conducted between September 2011 and July 2012 in Turin, and between October 2012 and January 2013 in Rome. The recruitment of participants was realized through snowball sampling, utilizing key informants like immigrant associations and NGOs. Gender, place of birth and year of arrival in Italy were used to stratify the sampling.

The interviews were led in Italian; occasionally, if migrants could not speak good Italian, English or Arabic was used. A semi-structured questionnaire was used that included various aspects of life and the migration experience. The following topics were addressed during the interviews: arrival in Italy, sense of community belonging and social participation, intergenerational relationships, transnational ties with Morocco and Egypt (in political, economic, family and symbolic terms), new media use, opinions about the current situation in Morocco and Egypt, and future plans and intentions to return. During the interviews participants spontaneously referred to policies and rules concerning immigration, as we had not included policy-related questions in the guideline. Interviews, lasting on average 60 
minutes, were audio-taped and transcribed. As interviewees were guaranteed confidentiality, fictitious names have been used throughout the paper.

Socio-demographic characteristics of the sample are presented in Table 1. More men than women were interviewed - 37 men and 22 women - with an average age of 47 years for Moroccans and 43 for Egyptians. The duration of residence in Italy ranged from three months to 39 years, with a mean of 15 years for Moroccans and 16 for Egyptians. Mean age at arrival is about 30 for Moroccans and 27 for Egyptians. Most of the Moroccans and Egyptians interviewed arrived between 1989 and 1990, when the Martelli Law was in effect. More than half of both the Moroccan and the Egyptian sample is married, rarely to an Italian. The mean number of children is 1.5 for Moroccans and 2 for Egyptians. Educational attainment is rather high, especially for Egyptians: over $80 \%$ of them have completed secondary education or higher, while almost half of the Moroccan sample has completed secondary or higher education. Although the educational attainment of migrant residents in Italy is quite high (according to Integrometro database (Cesareo and Blangiardo, 2009), $42 \%$ has secondary education and $19 \%$ a university degree), in our sample migrants with a university degree are overrepresented, therefore some caution is needed while interpreting the results. In terms of occupation, many Egyptians work in the catering and retail sector and Moroccans are mainly employed in other tertiary sector activities. Almost all Moroccans are Muslim, while about 20\% of Egyptians are Coptic. About half of the sample visits the country of origin at least once a year. One-third of Moroccans and half of Egyptians send remittances and own a house in the country of origin.

$<$ Table 1 about here >

\section{Results}

Migrant status mobility

As mentioned in the Introduction, immigration policies contribute to define both the status and the status mobility of migrants (the latter refers to the changes in immigration status migrants experience during their life in the host country). This is why for our sample we have schematized their initial and follow-up statuses in Italy (Figure 1). The scheme shows that the majority of our respondents entered Italy with a visa, mostly a tourist visa, and $20 \%$ entered Italy without one. This does not mean, however, that all of the latter were illegal upon arrival, as a visa was not needed before 1990; this was the case for five Moroccans and four Egyptians from our sample. Apart from the undocumented ones, nearly all respondents who held a tourist visa became irregular for a while. These results are consistent with previous studies (e.g. Einaudi 2007; Finotelli and Sciortino 2013), according to which the overwhelming majority of irregular migrants in Italy see their visa expire but remain in the country - they are called "overstayers". With the exception of one, all the 
illegal respondents were legalized by one of the amnesty laws, thus obtaining a temporary permit of stay, whereas almost all migrants who held a work visa/job contract, study visa or family visa obtained a temporary permit of stay immediately after the visa expired. This reveals the advantages of having social capital (for family visitors) and human capital (official job, high education level). Results confirm that a permanent permit of stay can be obtained only after a temporary one. Moreover, permanent residence status, which appears to be more common among Egyptians than Moroccans, facilitates the likelihood of obtaining Italian citizenship, as it proves a duration of residence in Italy of at least 10 years. Still, given the strict conditions for obtaining Italian citizenship, less than $30 \%$ of our respondents have become citizens.

$<$ Figure 1 about here >

\section{Entry to Italy}

From Section 2 it can be concluded that over time, Italian governments, regardless of whether they were led by a centreleft or a centre-right coalition, have continuously given great attention to reducing illegal immigration by implementing special measures against it (Zincone 2006a). Although these measures were used more often for electoral and propagandistic purposes (Colombo and Sciortino 2004b; Tursi 2004) than with the concrete aim of reducing illegal entries, they have contributed to make rules for migrants' entry and residence in Italy more restrictive. The heightened policy restrictiveness has been experienced by our sample of migrants. Before 1990 a visa was not needed to enter Italy; a valid passport and some money were sufficient, as stressed by Abdel, who arrived in Italy in 1989. He came from a small town in Morocco, where he left a large family of nine brothers and sisters. He was the second member of his family to migrate, after his older sister who went to France in the 1960s through family reunification. As a university student in Morocco he could easily get a passport, and decided to come to Italy: At that time I was studying at the university and I knew that a lot of people in my town were going to Turin, so they issued me a passport and I arrived here without a visa. Back then it wasn't necessary to have a visa: proof of having the money to leave [to enter Italy, ed.] was enough (Mm1989). ${ }^{3}$ Even when holding a visa became necessary to migrate to Italy starting in the 1990s (Natter 2014), eligibility procedures to enter the country were more relaxed than today, especially for people who could demonstrate, through their plane ticket and job contract in the country of origin, that they intended to stay in Italy only for a short period of time - or, like Mariam, for those who had travelled to other countries before: We entered Italy with a tourist visa, we went to the Italian Embassy and we said that we wanted to make a trip. It was me, my husband and my

\footnotetext{
${ }^{3}$ The interview source is reported according to the following coding system: ' $\mathrm{M}$ ' and ' $\mathrm{E}$ ' represent Moroccans and Egyptians, followed by a specification of the gender of the interviewee ( $m=$ male, $f=f e m a l e)$ and by the year of arrival in Italy. Thus Em1989 refers to an Egyptian male who arrived in 1989.
} 
eldest daughter, who was one year old. We obtained the visa, because they saw that I had already travelled to the U.S. and the U.K., so it was easy for us to get a tourist visa (Ef1999). Mariam comes from a middle-class family in Egypt. All her siblings have a university degree. Mariam decided to come to Italy with her husband and eldest daughter because her sister was already living there. Contrary to expectations, her sister's network could not help them that much. After arriving in Italy, they stayed for a while undocumented: I was without a permit of stay for three years, and then the regularization was introduced. I worked as a caregiver and could obtain the permit of stay through the amnesty (Ef1999).

As shown in Figure 1, by staying in Italy after her visa expired Mariam is not an exception. Many have ended up settling down in Italy without regular documents, waiting to get regularized by an amnesty law or after signing a job contract, even if this meant living in unsafe conditions. As reported by Ahmed: It was difficult for me, I had no documents and I was always trying to hide (Em1985). Before coming to Italy, Ahmed tried to get a visa for other European countries (Austria and the Netherlands). When these efforts failed, he decided to travel to Italy as a tourist together with some of his Egyptian friends. In Italy, finding a job turned out to be very difficult and, above all, frustrating for Ahmed. After several months of searching, he found part-time jobs in the market and in a restaurant. Many other irregular migrants faced the same difficulties finding a job, as stressed by Sami: People who were looking for a job were used to standing in front of the coffee shop, in the marketplace. Employers or owners of a business who needed a worker came to the coffee shop and chose. [...] They could choose someone at your right or someone at your left, but not you, it was a random choice (Em1992). Sami, owner of a clothing store in Egypt, arrived in Italy with a one-month business visa to do some import-export activities with clothes, and was lucky to find a job soon. He got a job in the market within few days thanks to the help of his brother, who had been living in Italy since 1988.

\section{Regularization}

To obtain a residence permit, irregular migrants were pushed to circumvent the rules by "buying" a labor contract. In many cases they got help from their employer, for whom they worked illegally, or they could benefit from the help of a different employer or an acquaintance. Mustapha's story is illustrative here. Mustapha, aged 45, arrived in Italy in 1994 with a regular visa. He decided to go to Turin, where his brother was living. In Morocco, after finishing high school, he worked with his father as a farmer. He migrated to Sweden but had to return to Morocco after a few months because he was illegal. Then he decided to get a visa to Italy. At the beginning he worked occasionally as a street seller. After struggling for one year, he found a job as a mason: I worked without a regular labor contract for almost two years. When the amnesty was introduced in 1996 through the Law Dini, I obtained the permit of stay. I met a family in Chieri and asked them to help me find a job, and they helped me. The family was composed of two parents and one daughter, 
who was still studying and who was really nice to me. She asked her parents to find a job for me. Their parents were just employees, so they could not hire me, but she was studying with the daughter of a man who had a small bicycle factory in the province, in Chieri. They asked him if I could work for him. He was a good Moroccan and he hired me with a six-month labor contract. I went to work there, I received the documents, but he subtracted a sum of money from my salary because he had to make a payment for my permit of stay (Mm1994).

In addition to enlisting the help of employers and acquaintances, migrants often asked for help from charitable associations. In the past, acting against the law, Caritas offered migrants proof that helped demonstrate that they were already in Italy at the moment an amnesty law was introduced. Accordingly, Caritas has been defined as an "agent of benevolent contra legem practices" (Zincone 1998: 45). Ali, for example, was the oldest of nine children from a small town near Casablanca. After finishing his theological studies in Morocco he could not find a job, so he decided to come to Italy because he heard that with the Martelli Law in 1990 it was easy to get a permit of stay. Ali tells: In 1990, to be regularized through the Martelli law it was necessary to demonstrate your presence in Italy in 1989. I could not prove that. So I went to Palermo, because there I could buy a permit of stay for 1 million lire [1,060 euros, ed]. In Turin I applied for the regularization, but they asked for proof of residence in 1989; a statement that you had been to the hospital could be sufficient, or a letter that you received from Morocco in 1989. Someone obtained such proof from Caritas. In that period Caritas helped many foreigners, but after a while the police stopped accepting this (Mm1990). Caritas is very appreciated by migrants, not only for the help received in making up documents but also for its practical and moral assistance during the first stages of their residence in Italy. Kenza and her family, for example, are facing serious difficulties because her husband does not have a permanent job. At the beginning of their stay in Italy, ten years ago, she did work, but stopped to care for her two children. Fortunately, she could count on the help of Caritas: Once every 15 days they gave me some cheese, milk and biscuits. Caritas was close to my home and they were very nice. They also gave me some clothes and shoes for the children. I think that without their help I would be dead (Mf2002). The role of Caritas and other Catholic associations in supplying social services to migrants (Della Porta, 2000) and in facilitating migrants' integration (Moya 2005; Schrover and Vermeulen 2005) is well recognized at several levels, and many migrants prefer such organizations to migrant associations. This is stressed by Mustapha when he talks about the experience of the Moroccan community residing in Turin: In Italy, these [Moroccan] associations do not help people obtain documents. They do not help orientate migrants, many migrants don't even know which association they can approach to ask for help. So migrants turn to Italian associations, such as Caritas. This means that Moroccan associations practically do not exist, and if they exist they act for their own interests. Most of the migrants who have their family here go to Caritas, which provides good beds (Mm1994). 
Not all problems are solved by obtaining legal status: migrants have to face the monetary costs to get and renew documents, which have increased over the years. Abdel-llah, who has lived in Italy for 25 years with his wife and three children and currently holds a permanent residence permit, reports about this: I have to tell you the truth, in Italy the problems are mainly the costs for renewal of residence permits. The costs have now reached 200 euros for a permanent residence permit, so a family with three children would have to pay 1000 euros. When I did it I paid 10.33 euros, then with the Bossi-Fini law the costs went up to 80 euros, and now it has reached 200 euros (Mm1992). Abdelllah works as martial arts instructor and is particularly close to other migrants, especially young migrants who face integration problems. He is very active in migrants' associations in Italy so he can help make their life more comfortable, especially when dealing with bureaucratic difficulties. The high costs for documents are perceived as even more unfair by migrants, considering that the procedures to get a permit of stay may last for a long time. Abdel-1lah stresses: The procedure to get a permit for two years takes four months, so in reality you get the permit for two years minus four months, and a month before the expiration you must submit the documents for renewal (Mm1992). The short validity of staying permits is another reason why migrants complain about the costs of documents, as reported by Kenza, who entered in Italy in 2002 under the Bossi-Fini Law and still has temporary resident status. As mentioned before, she is facing economic difficulties, so the price of getting the permit of stay each time seems highly unfair to her: We paid 80 euros for the permit of stay. Since I'm unemployed, the permit will be valid only for six months. In the past, the permit of stay was valid for two years. So now I have to pay 200 euros for six months and my husband needs to pay the same (Mf2002).

A regular job for migrants is not only an important condition per se, it serves the process of status mobility and therefore facility of access to certain categories of migration or transfer from one category to another. Magdi, who arrived in Italy in 1980, initially worked as servant, then decided to start his own commercial activity; he stresses the differences between an Italian and a migrant employee: Foreigners always need a labor contract in order to renew their staying permits (Em1980). Having a work contract is not enough to renew a permit of stay, many migrants indeed stress the need of having a permanent job, as explained by Tamer, employed for the last 14 years at Pirelli (an Italian multinational company in the tire sector): Even if you receive a basic salary, the important thing is that you have a permanent job (Em1993). This is corroborated by Saana, who entered Italy in 1999 with a visa for elderly care and works as a caregiver for an old lady. The temporary contract she used to have working at a hotel was not conducive to getting permanent residence: To work in a hotel you just sign a 6-month contract, but with this contract you cannot obtain the permit of stay. You need a permanent contract (Mf1999).

In Italy, as in other immigrant countries, the process of integration often tends to privilege the economic dimension and consequently the inclusion of migrants into the labor market (Castles, 1995). Nevertheless, it can take 
the form of a "subordinate integration" (Ambrosini 2005), according to which migrants are confined to certain sectors and occupations which are generally refused by natives because they are considered unpleasant, low-qualified and, above all, associated with an "inferior social status" (Piore 1979: 17). These characteristics "ethnicize" such occupations (Ambrosini 2013: 183) - they become limited to migrants and in particular to certain ethnicities. Rachida, for example, arrived in Europe in 2005 to follow an international Master's program. At the end of the program, after an internship in Turin, she decided to stay in Italy so she spent three years undocumented. She finally regularized her position by going back to Morocco and getting a new visa for a $\mathrm{PhD}$. After a long experience in Italy she thinks that: The only type of work which is still available to migrants is that of caregiver, because there are so many old people who need help, and the caregiver is almost always a woman (Mf2005). Abdel-llah highlights the same trend: Women are working as baby-sitters or caregivers for elderly people, or as cleaning women. Maybe you can find Romanian women working in some firms, but never Moroccan women (Mm1992).

\section{Family reunification}

Family reunification can be considered "the main reason for permanent entry" (Reyneri 2001: 13) in Italy. Indeed, the foreign resident population is composed mainly of migrants who benefitted from an amnesty law and their family members who entered Italy through family reunification (Barbagli et al. 2004). Family reunification has sometimes been used as an ex-post instrument to regularize family members already present in Italy at the moment of application. Some of them left Italy temporarily to return as family migrants, sometimes accompanied by a newborn child. This is the case of Ramy, who arrived in Italy in 1989, was regularized with the Martelli Law (1990), and currently has a permanent job: I asked for family reunification. My wife arrived immediately in June, because I had already prepared the house and then with all the documents we asked for family reunification. After six months she went to Egypt and in the meantime the regular visa for family reunification arrived and so she returned here again. When my wife was in Egypt my daughter was born and then we needed to get new documents. Fortunately, it was only necessary to add the name of the child on the passport, without doing a new application for family reunification (Em1989).

To prevent such ex-post regularizations, conditions regulating family reunification rights in Italy became stricter over time. Since 1995, migrants who ask for family reunification must prove having a minimum income and a proper accommodation, as reported by Sherif, who benefitted from family reunification in 2003 thanks to the fact that he had been working at a waste disposal company for a long time. He says that this is not the case for everyone though, because: It is not easy. You need to have a job [to have a minimum income, ed] and a house (Em1997). The Dini Decree (1995) additionally imposed that family migrants' accommodation can be subjected to certifications by competent council offices, charged to testify the size and hygienic conditions of the house (Cento Bull, 2010). This 
happened to Sami, who arrived in Italy in 1992 and asked for family reunification after marrying an Egyptian woman in Egypt in 2000: To obtain the family reunification I needed to have a house here and to call a Chartered Surveyor to check if the house was okay for a family. Without a house I could not obtain the family reunification, so a Chartered Surveyor came and checked the house to see if it had minimum square footage (Em1992). Despite the increase in restrictiveness of procedures, migrants continue to resort to family reunification by legal or illegal means. Said arrived in Italy in 1990 and spent more than 15 years there before starting the procedure for family reunification for his wife and six children: In 2004, my son arrived without documents and I could not ask for the family reunification. He has been living with me for three years without any documents. Then in 2007 my wife and my daughter came (Mm1990).

\section{Italian citizenship}

The importance of citizenship rights for migrants' full incorporation into the host society has been largely demonstrated (e.g. Bauböck 2006; Castles 1995; Koopmans and Statham 1999; Zincone 1992), yet in Italy the acquisition of citizenship rights is still problematic due to the restrictive conditions and the elaborated bureaucratic procedures, as presented in Section 2. It is well acknowledged (Pastore 2004; Zincone 2006b) that the current Italian legislation on citizenship rights, which dates back to 1992, is still more favorable to Italian emigrants abroad and their descendants than for immigrants living in Italy. This is surprising, given the size of the immigrant population residing in Italy and the structural character of immigration to the country. Despite the partial reform implemented in 2013 (cf. Section 2), the Italian parliamentary debate about a comprehensive reform of citizenship rights legislation is still rather vague and inconsistent.

The acquisition of citizenship rights is clearly perceived by migrants living in Italy as rather difficult and timeconsuming. Amina has lived in Italy for 15 years and entered with a tourist visa. Together with her husband she decided to come here from Morocco to get better medical care for her daughter, who has the Down syndrome. After years of struggling to find work and get regularized, they could finally apply for citizenship. Amina complains of the long waiting period to become Italian: We obtained Italian citizenship one year ago, but we had to wait a long time to get it. This is the only country where you have to wait for 10 years... as a permanent resident, eh? Because if you don't have permanent residency, instead of 10 you could also wait for 20 [years]! (Mf1998). Sometimes the main problem is the long time it takes to receive feedback once the application has been made and, above all, the lack of transparency of authorities' discretionary practices in granting the citizenship rights (Triandafyllidou 2003). As Tamer reveals: I applied in March, so it's three years ago that I have applied. (Interviewer: So in three years you haven't yet received any answer?) Yes, I don't know what to do. The answer should arrive from Rome. I've had had a permit of stay for more than 10 years. I've never had any problems (Em1993). 
When it comes to migrants' children born in Italy, the law regulating acquisition of citizenship rights is considered particularly unfair and detrimental to the process of mutual acceptance between migrant and society. As reported by Fatima: If you are born in Italy, have studied in Italy, you are Italian! When you are 18 years old they cannot ask you to line up at the police station, saying that you aren't Italian. You can tell them: “I'm Italian!'. All this is dangerous, because it creates a situation of stress and can open the road to extremism. Why don 't you give citizenship to this young one? That child feels Italian. Integration derives from acceptance. If you don't accept a person, that person will never feel integrated (Mf1981). Fatima arrived in Italy more than 30 years ago after marrying an Italian man she met while he was working in Morocco. She directly became an Italian citizen. As she works in the Italian Parliament, she is aware of the difficulties that people with an immigrant background face in everyday life in Italy. It is evident from her words that migrants see citizenship by birth for second generations as conducive to a successful immigrant integration process.

Although migrants are aware of the difficulties they might meet in applying for Italian citizenship, not all are discouraged to do so, given its multiple benefits. In the first place, although it may seem obvious, Italian citizenship confers a more stable and safe residence in Italy, compared to any other kind of documents. As Sami tells: Italian citizenship gives more confidence to live here. The permit of stay is not $100 \%$ safe, because when you have to renew it they ask you for all the documents about your work position since you entered Italy. If I lose my job, for instance, then I will lose the permit of stay too (Em1992). Italian citizenship also allows people to easily travel to their country of origin without any particular restriction to the possibility of eventually returning to Italy whenever they wish. According to Tamer: I want to return to my country of origin, I'm waiting to obtain Italian citizenship (Em1993). Lastly, with Italian citizenship migrants can move freely between countries in the European Union, as stated by Mustapha: With Italian citizenship you have the right to obtain some benefits. You can go to other countries, such as Belgium and France (Mm1994). Belgium and France are also quoted as countries where obtaining citizenship rights is faster compared to Italy. Amina explains: Most migrants have moved to France and Belgium, and all of them obtained citizenship after almost two years (Mf1998). Migrants are attracted to other European countries mainly because of the better living conditions they expect to find there. Najat, who regrets her choice of coming to Italy because she has relatives here, explains: I noticed that those who have Italian citizenship went to Belgium or to France to find accommodations. As soon as they found it, they brought their family with them. Social services are better there, compared to here. Women who stay at home with their children receive a grant, families with children under 18 receive a financial subsidy, and they are allowed to work there or in Morocco (Mf1994). A more decent treatment of the foreign population is another factor pushing migrants to leave Italy, which is not perceived as very inclusive at the moment. Abdel-llah declares: Italy is still not ready to host migrants. It is not only a problem of labor and social conditions, it is a problem of how Italians 
perceive and treat migrants (Mm1992). Hence the main worries of many Italian policymakers and Italian families notwithstanding that migrants want to have Italian citizenship to ask for more social services, economic opportunities or political representation in Italy (Ambrosini 2013; Cento Bull 2010), migrants' main motives are actually related to increasing the possibilities of circular mobility.

\section{Discussion and Conclusion}

This paper examined the ways in which Italian immigration policies have had an impact on the lives of Moroccan and Egyptian migrants. We defined the impact of immigration policies as the ensemble of intended and expected effects, unexpected and unintended consequences, and migrants' perception of immigration policies, and explored this impact by examining qualitative data among first-generation Moroccans and Egyptians residing in the Italian cities of Turin and Rome. We focused on the following circumstances: entry to Italy (including family reunification), regularization and citizenship. We have built on the review of the theoretical and empirical debate, analyzed by Cornelius and Rosenblum (2005), Joppke (1998), Ruhs (2008) and Schuster (2005): their research stresses that immigration policies produce intended consequences like the status of migrants and the categories according to which they are classified, but also emphasizing the weaknesses of some policy decisions and their tendency to produce unexpected and unintended consequences.

Although immigration is a structural component of the Italian society and labor market (Bascherini 2007; Colombo and Sciortino 2004a), Italian policymakers continue to perceive it as a temporary phenomenon. Regardless of political color, Italian governments have increasingly tried to counteract the arrival of new immigrants by introducing more restrictive admission criteria (including those applying to migrants' family members through family reunification), greater control at the borders, and stricter rules regarding the detention and deportation of illegal migrants. The conditions for renewing residence permits and rights to citizenship by marriage have become more demanding over the years and, despite efforts of some political parties and civil society, second-generation migrants are still not granted citizenship by birth.

In line with previous studies (Castles 2004b; Geddes 2008; Gilligan 2015), our findings attest to the ineffectiveness of Italy's restrictive entry policies, mainly because of other government actions that contradict the general repressive approach towards immigration. The viewpoint of migrants as unwelcomed and undesirable has been mitigated by awareness of migrants as needed and wanted by the Italian labor market. As perfectly elucidated by Ambrosini (2013), several factors, such as the demographic process of population aging and the vast and increasing demand of cheap labor force, underlie a gap between the restrictive rules for entry and residence in Italy and the process of social acceptance of migrants at both the societal and the institutional level. The need for foreign female caretakers of 
Italian elderly and children (badanti) and the structural demand for male laborers in the agricultural and catering sectors lead people to tolerate the presence of migrants in Italian society and even to integrate them into their families. Contextually, Italian governments have legitimized their presence by legalizing irregular migrants through amnesties and by introducing annual work quota systems which set the number of migrants that may enter the country and are granted a work and residence permit. As shown in this paper, non-eligible persons have also benefitted from these nonrestrictive measures, often with the help of Caritas and others (e.g. employers, co-ethnic friends, Italian families) to obtain the right work and residence documents. As a consequence, most of our Moroccan and Egyptian migrants who entered the country with a tourist visa, succeeded to stay in Italy by bypassing legislation, then waiting for the next amnesty, often in tough conditions (e.g. fear of police control) after the visa expired; almost all who entered Italy for family, work or study reasons obtained a temporary residence permit directly after the expiration of their visa or job contract, indicating the relevance of social and human capital. Once they had the legal status, no far-reaching legislation hindered them from either bringing in their spouse and minor children or regularizing the family members already in Italy (Colombo and Sciortino 2004b), as opportunities for family reunification are still very generous despite stricter conditions over time. This finding confirms that family migration is one of the major entry channels for Italy (Reyneri 2001).

Despite the alleged unsuccessful efforts to control the migration inflow, Italian governments appear to be more effective when it comes to complicating the issuing and maintenance of migrants' legal status and to putting roadblocks to status mobility, which enables migrants to navigate temporary and permanent residency on their way to citizenship. Over time, the costs of obtaining and renewing a temporary residence permit have dramatically increased, the period of validity of the permit has been shortened, and the requirements have become more stringent. Together with the long waiting times to obtain temporary residence, these changes have a strong negative impact on migrants' lives, not only in economic terms but also psychologically (living in constant uncertainty about the future). The procedures to obtain permanent residence and Italian citizenship have also become more costly and restrictive over time, and they are perceived by our Moroccan and Egyptian migrants as highly unfair. These measures prevent them from becoming and feeling like full members of Italian society. The difficulty involved in obtaining Italian citizenship is especially viewed as a travesty for their offspring and is to some extent counterproductive: not having Italian citizenship hinders circular migration, return migration or moving to another country - which is the wish of a non-negligible number of our Moroccan and Egyptian migrants - factors that would foster their permanent settlement (Massey et al. 2014).

In sum, the increased restrictiveness in immigration policies is not and will not be effective to reduce the number of entries, as migration is driven by structural factors such as demographic change, economic needs and transnational networks. However, policy restrictiveness largely affects migrants' status mobility in a negative way and 
hence their capabilities to be part of the host country. Besides hindering integration and future migration projects, such restrictiveness undermines social cohesion. 


\section{References}

Ambrosini, M. (2005). Sociologia delle migrazioni [Sociology of migration]. Bologna: Il Mulino.

Ambrosini, M. (2013). Immigration in Italy: between economic acceptance and political rejection. Journal of International Migration and Integration, 14(1), 175-194.

Barbagli, M., A. Colombo, \& Sciortino, G. (2004). I Sommersi e i sanati. Le Regolarizzazioni degli immigrati in Italia [The regularisations of immigrants in Italy]. Bologna: Il Mulino.

Bascherini, G. (2007). Immigrazione e diritti fondamentali [Immigration and fundamental rights]. Napoli: Jovene.

Bauböck, R. (Ed.) (2006). Migration and citizenship: legal Status, rights and political participation. IMISCOE Report Series. Amsterdam: Amsterdam University Press.

Castles, S. (1995). How nation-states respond to immigration and ethnic diversity. Journal of Ethnic and Migration Studies, 21(3), 293-308.

Castles, S. (2004a). The factors that make and unmake migration policies. International Migration Review, 38(3), 852884.

Castles, S. (2004b). Why migration policies fail. Ethnic and Racial Studies, 27(2), 205-227.

Cento Bull, A. (2010). Addressing contradictory needs: the Lega Nord and Italian immigration policy. Patterns of Prejudice, 44(5), 411-431.

Cesareo, V., \& Blangiardo, G. C. (2009). Indici di integrazione. Un'indagine empirica sulla realtà migratoria italiana, [Integration indexes. An empirical survey on the Italian migration context]. Milano: Franco Angeli.

Cingolani, P., \& Ricucci, R. (2013). Transmediterranei. Le collettività di origine nordafricana in Piemonte, tra continuità e cambiamento [Transmediterraneans. North African communities in Piedmont, between continuity and change]. FIERI Research Report. Turin: FIERI.

Colombo, A., \& Sciortino, G. (2004a). Alcuni problemi di lungo periodo delle politiche migratorie italiane [Some longterm problems of Italian migration policies]. Le Istituzioni del Federalismo, 5, 763-788.

Colombo, A., \& Sciortino, G. (2004b). Gli Immigrati in Italia [Immigrants in Italy]. Bologna: Il Mulino.

Cornelius, W. A. (2005). Controlling 'unwanted' immigration: lessons from the United States, 1993-2004. Journal of Ethnic and Migration Studies, 31(4), 775-794.

Cornelius, W. A., \& Rosenblum, M. R. (2005). Immigration and politics. Annual Review of Political Science, 8, 99119.

Cvajner, M., \& Sciortino, G. (2010). A tale of networks and policies: prolegomena to an analysis of irregular migration careers and their development paths. Population, Space and Place, 16(3), 213-225. 
Czaika, M., \& de Haas, H. (2013). The Effectiveness of immigration policies. Population and Development Review, 39(3), 487-508.

De Haas, H., \& Vezzoli, S. (2011). Leaving matters. The nature, evolution and effects of emigration policies. DEMIG Project Paper No. 4. Oxford: IMI.

Della Porta, D. (2000). Immigration and protest: new challenges for Italian democracy. South European Society and Politics, 5(3), 108-132.

Einaudi, L. (2007). Le Politiche dell'immigrazione in Italia dall'unità ad oggi [Immigration policies in Italy from the unification to Nnowadays]. Roma-Bari: Editori Laterza.

Eurostat online dataset. http://ec.europa.eu/eurostat. Accessed December 1, 2015.

Finotelli, C., \& Sciortino, G. (2013). Through the gates of the Fortress: European visa policies and the limits of immigration control. Perspectives on European Politics and Society, 14(1), 80-101.

Geddes, A. (2008). Il Rombo dei Cannoni? Immigration and the centre-right in Italy. Journal of European Public Policy, 15(3), 349-366.

Gilligan, C. (2015). The public and the politics of immigration controls. Journal of Ethnic and Migration Studies, doi:10.1080/1369183X.2015.1021584.

ISMU 2011 XVII Rapporto sulle migrazioni in Italia [XVII Report on migration in Italy]. Milano: Franco Angeli.

Istat online dataset. http://demo.istat.it. Accessed March 2, 2015.

Italian Ministry of Interior.

http://www.interno.gov.it/mininterno/export/sites/default/it/sezioni/ministero/dipartimenti/dip_politiche_personale/s tatistiche/scheda_15929.html. Accessed December 10, 2015.

Joppke, C. (1998). Why liberal states accept unwanted immigration. World Politics, 50(2), 266-293.

Koopmans, R., \& Statham, P. (1999). Challenging the liberal nation-state? Postnationalism, multiculturalism and the collective claims making of migrants and ethnic minorities in Britain and Germany. American Journal of Sociology, $105(3), 652-696$.

Massey, D. S., D. Jorge, \& Pren, K. A. (2014) Border enforcement and return migration by documented and undocumented Mexicans. Journal of Ethnic and Migration Studies, doi:10.1080/1369183X.2014.986079.

Mezger, C., \& Gonzalez-Ferrer, A. (2013). The ImPol Database: a new tool to measure immigration policies in France, Italy and Spain since the 1960s. MAFE Working Paper No. 34. Paris: INED.

Morris, L. (2001). The Ambiguous terrain of rights: civic stratification in Italy's emergent immigration regime. International Journal of Urban and Regional Research, 25(3), 497-516. 
Moya, J. C. (2005). Immigrants and associations: a global and historical perspective. Journal of Ethnic and Migration Studies, 31(5), 833-864.

Nascimbene, B. (1988). Lo Straniero nel diritto italiano [The Foreigner in the Italian Law]. Milano: Giuffré Editore.

Natter, K. (2014). Fifty years of Maghreb emigration. How states shaped Algerian, Moroccan and Tunisian emigration. DEMIG Project Paper No. 21. Oxford: IMI.

Pastore, F. (2004). A community out of balance: nationality law and migration politics in the History of post-unification Italy. Journal of Modern Italian Studies, 9(1), 27-48.

Pastore, F., \& Villosio, C. (2011). Nevertheless attracting. Italy and immigration in times of crisis. LABOR Working Paper No. 106. Turin: LABOR.

Piore, M. J. (1979). Birds of passage. Migrant labour and industrial societies. New York: Cambridge University Press.

Reyneri, E. (1998). The role of the underground economy in irregular migration to Italy: cause or effect? Journal of Ethnic and Migration Studies, 24(2), 313-331.

Reyneri, E. (2001). Migrants' involvement in irregular employment in the Mediterranean countries of the European Union. Geneva: International Labor Organization.

Ruhs, M. (2008). Economic research and labour immigration policy. Oxford Review of Economic Policy, 24(3), 403426.

Saraceno, C., N. Sartor, \& Sciortino, G. (2013). Stranieri e disuguali. Le disuguaglianze nei diritti e nelle condizioni di vita degli immigrati [Foreigners and unequal. Inequalities in the rights and living conditions of immigrants]. Bologna: Il Mulino.

Schuster, L. (2005). The continuing mobility of migrants in Italy: shifting between places and statuses. Journal of Ethnic and Migration Studies, 31(4), 757-774.

Schrover, M., \& Vermeulen, F. (2005). Immigrant organisations. Journal of Ethnic and Migration Studies, 31(5), 823832.

Sciortino, G., (2002). Islamofobia all'italiana [Italian Islamophobia]. Polis XVI (1): 103-123.

Solé, C. (2004). Immigration policies in southern Europe. Journal of Ethnic and Migration Studies, 30(6), $1209-1221$.

Triandafyllidou, A. (2003). Immigration policy implementation in Italy: organisational culture, identity processes and labour market control. Journal of Ethnic and Migration Studies, 39(2), 257-297.

Tursi, A. (2004). Il Lavoro degli immigrati nella legge Bossi-Fini: diritto comparato e politiche comunitarie [Immigrant labor in the Bossi-Fini law: comparative law and EU policies]. Italian Journal of Social Policy, 1(3), 91-120.

Vogel, D. (2000). Migration control in Germany and the United States. International Migration Review, 34(2), 390422. 
Zincone, G. (1992). Da sudditi a cittadini [From vassals to citizens]. Bologna: Il Mulino.

Zincone, G. (1998). Illegality, enlightenment and ambiguity: a hot Italian recipe. South European Society and Politics, $3(3), 45-82$.

Zincone, G. (2006a). The making of policies: immigration and immigrants in Italy. Journal of Ethnic and Migration Studies, 32(3), 347-375.

Zincone, G. (Ed.) (2006b). Familismo legale. Come (non) diventare Italiani [Legal familism. How to (not) become Italian]. Rome-Bari: Laterza.

Zincone, G., \& Caponio, T. (2004). Immigrant and immigration policy-making: the case of Italy. IMISCOE Working Paper Country Report. Amsterdam: IMISCOE. 
Table 1. Socio-demographic characteristics of the respondents $(\mathrm{N}=59)$

\begin{tabular}{lcc}
\hline & $\begin{array}{c}\text { Moroccans } \\
(\mathrm{N}=26)\end{array}$ & $\begin{array}{c}\text { Egyptians } \\
(\mathrm{N}=33)\end{array}$ \\
\hline Men & 13 & 24 \\
Mean age & 46.6 & 43.3 \\
Mean duration of residence & 15 & 16 \\
Mean age at arrival & 30.5 & 26.8 \\
Married $\quad 14$ & 24 \\
$\quad$ to an Italian & 2 & 4 \\
Mean number of children & 1.5 & 2 \\
Education: & & \\
$\quad$ primary or no education & 7 & 2 \\
$\quad$ secondary & 7 & 9 \\
$\quad$ university & 10 & 22 \\
$\quad$ unknown & 2 & \\
Occupation: & & \\
$\quad$ cleaning sector & 4 & 2 \\
$\quad$ catering sector & 2 & 2 \\
$\quad$ retail sector & 1 & 7 \\
$\quad$ other occupations in the tertiary sector & 15 & 11 \\
$\quad$ no job (student, unemployed, retired, housewife) & 4 & 11 \\
Religion: & & \\
$\quad$ Muslim & 23 & 26 \\
$\quad$ Coptic Christian & & 7 \\
$\quad$ Unknown & 3 & \\
Visit their country of origin at least once per year & 14 & 18 \\
Send remittances to their country of origin & 8 & 17 \\
Home ownership in their country of origin & 11 & 15 \\
\hline
\end{tabular}


Figure 1: Migrant status history of the respondents

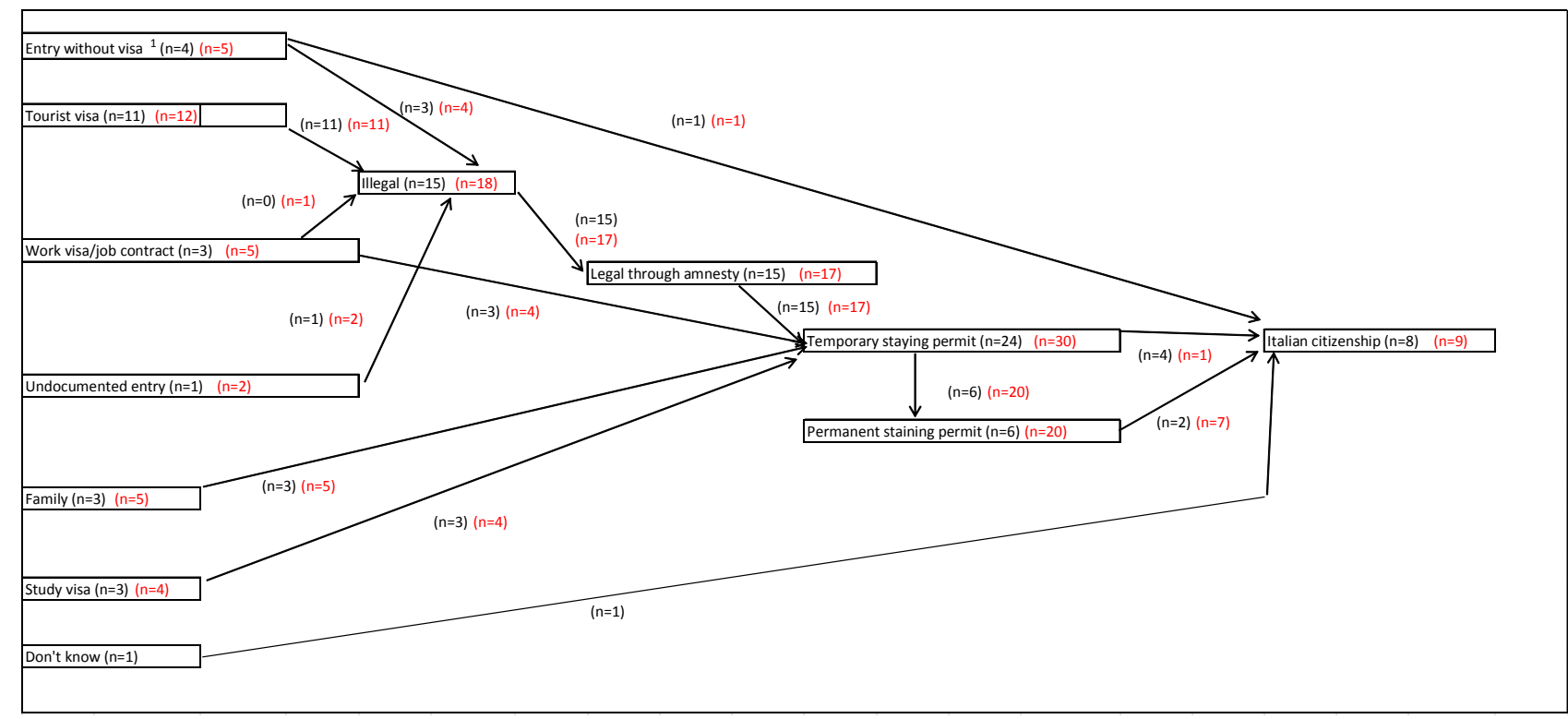

Notes:

1. Entry without visa: includes migrants that entered Italy before 1990 when a visa was not needed.

2. Different colors: black $=$ Moroccans, red = Egyptians . 


\section{Appendix 1. Immigration policy reforms in Italy, 1912-2013}

\section{Year Month Number Typology Description}

$19126 \quad 555 \quad$ Law: Italian citizenship

By birth (Ius sanguinis): children of an Italian male citizen; children of an Italian female citizen if the father is unknown, if the father is stateless or if children do not take the citizenship of the non-Italian father in accordance with his country's legislation. A foreign citizen born in Italy or whose parents have resided in Italy for 10 years becomes Italian if: he does military service in Italy, if s/he works for the Italian government; at the age of $21 \mathrm{~s} / \mathrm{he}$ is an Italian resident and applies for Italian citizenship no later than his/her 22nd birthday ; s/he has been an Italian resident for at least 10 years and does not choose to keep his/her foreign citizenship by his/her 22nd birthday.

Other reasons to acquire Italian citizenship: having served the Italian state for three years, in Italy or abroad; having resided for at least five years in Italy; having resided for two years in Italy and rendered outstanding service to Italy or contracted marriage with an Italian citizen; after six months of residence, for those who could have become Italian citizens but failed to expressly apply for citizenship timely.

\begin{tabular}{lll}
\hline $1931 \quad 6 \quad 773$ & $\begin{array}{l}\text { Testo Unico delle leggi di } \\
\text { pubblica sicurezza: on norms } \\
\text { of public security }\end{array}$
\end{tabular}

No visa required to enter Italy.

After three days of arrival in Italy, all foreigners must declare their presence to the police, at which time it issues the foreigner a permit or authorization of stay.

An Italian employer hiring a foreigner should declare that to the police within five days of the beginning and end of the contract.

\begin{tabular}{|c|c|c|c|c|}
\hline 1963 & 12 & $51 / 22 / \mathrm{IV}$ & Circolare of Ministry of Labor & $\begin{array}{l}\text { In order to work in Italy, (1) non-EEC citizens need an entry visa for work and (2) foreigners need a work authorization and a work } \\
\text { staying permit, which regulate new entries. Foreigners residing in Italy who entered the country for reasons other than work but are } \\
\text { already active on the labor market, are exempted from this requirement. }\end{array}$ \\
\hline 1970 & 12 & 7 & $\begin{array}{l}\text { Circolare riservata of Ministry } \\
\text { of Foreign Affairs, regulating } \\
\text { entry, residence and transit of } \\
\text { foreigners }\end{array}$ & $\begin{array}{l}\text { To enter Italy a foreigner must be in possession of a passport and, if required (also Moroccans and Egyptians), an entry visa issued by } \\
\text { consular authorities. } \\
\text { The activities permitted during the period of stay are not specified. Study and work are managed by other laws (see the above-mentioned } \\
1963 \text { circular). }\end{array}$ \\
\hline 1973 & 1 & 2 & $\begin{array}{l}\text { Circolare riservata of Ministry } \\
\text { of Foreign Affairs, regulating } \\
\text { entry and transit visa of } \\
\text { foreigners }\end{array}$ & Need for scrupulous observance of rules on visas already issued by the circulars of 1963 (work visa) and 1970 (tourist visa). \\
\hline 1979 & 1 & $443 / 225388$ & $\begin{array}{l}\text { Circolare of Ministry of } \\
\text { Interior, regulating entry and } \\
\text { residence of foreigners }\end{array}$ & $\begin{array}{l}\text { With this circular the Italian government intended to simplify the issuance of residence permits and rationalize the planned entry } \\
\text { procedures, in order to have a more effective control system. }\end{array}$ \\
\hline 1981 & 4 & 158 & $\begin{array}{l}\text { Law ratifying ILO } \\
\text { Conventions } 92,133 \text { and } 143\end{array}$ & $\begin{array}{l}\text { Ratification of the ILO convention on migrant workers, guaranteeing basic human rights and work rights (social benefits, strikes, labor } \\
\text { union membership) as well as family reunification to migrant workers. Receiving countries should promote integration of migrant } \\
\text { workers. Receiving countries lacking proper legislation on migrant workers should create proper legislation in accordance with the ILO } \\
\text { convention. }\end{array}$ \\
\hline 1982 & 3 & $\begin{array}{l}443 / 186378 \\
/ 5 / 11 / 3 / 1 / 2\end{array}$ & $\begin{array}{l}\text { Circolare of Ministry of } \\
\text { Labor: regulates foreigners' } \\
\text { access to the labor market } \\
\text { Circolare of Ministry of } \\
\text { Interior: regulates non-EU } \\
\text { citizens' access to the labor }\end{array}$ & $\begin{array}{l}\text { Aim: to block recruitment of new employees from non-EU countries. New work permits not issued. } \\
\text { Amnesty for existing work de facto for workers who entered before } 31 \text { December 1981. Conditions: To have entered Italy for the } \\
\text { purpose of work (not as a student). Employer deposit of an amount of money equivalent to the price of a flight ticket to the foreigner's } \\
\text { country of origin and foreign worker's medical certificate of good health. }\end{array}$ \\
\hline
\end{tabular}


15106/IR/A market

\begin{tabular}{llll}
\hline 19834 & 123 & Law: Italian citizenship & $\begin{array}{l}\text { Citizenship by marriage to an Italian can be granted after six months of regular residence in Italy from the marriage date or after three } \\
\text { years from the marriage date for those residing abroad. }\end{array}$
\end{tabular}

The children of an Italian man or woman are Italian citizens (citizenship by mother or father transmission).

$19862 \quad 4,5,6,7 \quad$ Circolare of Ministry of Foreign Affairs introducing entry visa for Algeria,

Morocco, Tunisia, Kenya

$198612 \quad 943 \quad$ Foschi Law: on placement and treatment of foreign workers and immigrants, against illegal immigration

To enter and have residence in Italy, immigrants need a work visa and work authorization issued by the labor offices. Work authorization should be issued before the visa and lasts two years.

Amnesty should be granted within three months of Foschi enforcement. Conditions: non-EU workers present in the Italian territory when the law was enforced were obliged to regularize within three months of the start of the amnesty period. Workers looking for a job could also regularize their position by registering at the local employment office as job-seekers.

Similarly, employers should declare irregular workers employed in their company. Foreigners should hold a passport or an officially witnessed declaration of identity.

Non-EU workers ${ }^{4}$ who lose their job (and their legally resident family members) keep the residence permit. The law requires compilation of a list of non-EU workers (and their family members) who were already in Italy.

Monthly census to recruit workers from abroad: entrepreneurs could ask a quota of workers. The employer must demonstrate that there is no Italian or EU citizen available for that job.

Family reunion: for spouse, minor non-married children (economically dependent) and parents (economically dependent). The reason to access Italy should not be looking for a job, but working is permitted after one year of regular stay.

\begin{tabular}{llll}
\hline 1990 & 3 & 1 & Martelli Law: regulates entry
\end{tabular} and residence of non-EU

citizens. Migration starts to be seen as a stable phenomenon. Defines the conditions to gran entry permits for work reasons: the government must draw up a yearly plan instead of referring to pre-defined criteria. First law to introduce the idea of quotas, promoting regularization for about 250,000 migrants.

Entry: Non-EU citizens' passports are stamped at the border. Their entry is recorded at the border and sent to the Ministry of the Interior. Visa (where prescribed, including Moroccans and Egyptians) and passport are required to enter the Italian territory. The Ministry of Foreign Affairs establishes the need for an entry visa according to bilateral agreements. Visa should specify reason of entry, duration of stay and number of entries. Visas are single-entry and valid for three months, and should be accompanied by proof of financial resources (goods and services in Italy or a guarantee).

Entry for work reasons: every year, by October 30, a quota of needed non-EU workers should be prepared by law - the Flows Decree.

Residence: Staying permit should be demanded within eight days of entry and is given for the reasons stated on the visa. It is issued for two years for most reasons of stay. It can be renewed for a duration double of the original one, and can be used for a purpose different than the original (if given for work, study or family reasons). Renewal of the permit is issued only if the migrant or his/her family member (the same family members specified in the law of 1986) show having a minimum income (=social pension) and proper housing. For non-EU citizens married to an Italian citizen and resident for more than three years, the duration of the staying permit is unlimited. Amnesty: non-EU citizens living in Italy before 31 December 1989 could be regularized. Conditions: they need to demonstrate their presence in Italy, appealing to e.g. acquaintances and institutions (such as religious and cultural associations for migrants). Open to all foreigners (non-EU and stateless) resident in Italy by 31/12/1989 regardless of the purpose of their stay. They could ask for a two-year staying permit for work, study or job-seeking. To be regularized, foreigners should have a passport or a declaration of identity witnessed by two Italians and the mayor of the city of residence, and proof of presence in Italy when the regularization started.

\footnotetext{
${ }^{4} \mathrm{http}$ ///epp.eurostat.ec.europa.eu/statistics_explained/index.php/Glossary:Extra-EU.
} 
Law defining a new regulation on citizenship:

1) option to keep dual nationality

2) definition of new

possibilities for descendants of

Italian citizens who want to reclaim Italian citizenship

3 ) new limitations for

descendants) who want to

obtain Italian citizen

$\begin{array}{llll}1995 & 4 & 489 & \text { Dini Decree: allows }\end{array}$

regularization of over 250,000 migrants. Schengen treaty rules on visas and entry: each EU member country that signed Schengen must adopt the rules on border-crossing and visa policies. foreigners (not Italian

Foreign citizens born in Italy and residing legally until age 18 can apply for Italian citizenship within one year of their 18th birthday. Citizenship by marriage to an Italian can be granted after six months of regular residence in Italy from the marriage date, or after three years from the marriage date for those residing abroad.

Citizenship by residence, EU citizens: granted after four years of residence.

Stateless citizens: granted after five years of residence.

Non-EU citizens: granted after 10 years of residence.

Citizenship by residence: show income statement/tax return of applicant or supporting family member for the three years prior to citizenship application date. The minimum yearly income should be $€ 8,300$.

Seasonal workers: yearly Flows Decree should also indicate number of seasonal workers. They require a visa to enter Italy for seasonal jobs, and once in Italy must request a nonrenewable six-month staying permit for seasonal work.

Family reunion: after one year of regular entry and residence, non-EU citizens can ask for family reunion for their spouse and minor children. The condition of proper housing should be fulfilled and the monthly income should be at least double that of the social check (about $£ 450,000, € 232$ ) for the spouse and two children (amount doubled for any additional two children). The permit is valid for two years and can be renewed.

Amnesty: regularization for dependents, work and family reunification. As in the previous regularization, foreigners must have a passport or declaration of identity witnessed by two Italians and the mayor of the city of residence, as well as proof of presence in Italy when the regularization started.

Regularization for family reunion: i.e. for spouse and minor children (not for parents) within 60 days of Dini enforcement, for family reasons, for two years and renewable for two years. The applicant should have proper housing (verified by the police) and an income a least double that of the social check.

Regularization for irregular workers and residents: within 120 days of Dini enforcement, non-EU citizens present in Italy could be regularized if the/an employer offers immediate availability of a job. Those migrants who could show they worked in the previous four months could also be regularized. Two-year staying permits are given for fixed-term contracts of more than two years or for permanen contracts. Six-month staying permits are given to foreigners registered in the local placement/employment office's list of job-seekers.

\begin{tabular}{|c|c|c|}
\hline $1998 \quad 10$ & 5 & $\begin{array}{l}\text { Promotion of a new } \\
\text { regularization program }\end{array}$ \\
\hline $\begin{array}{ll}1998 \quad 7\end{array}$ & 286 & $\begin{array}{l}\text { Legislative Decree (Turco- } \\
\text { Napolitano) or "Single Text of } \\
\text { Immigration Law"; collects in } \\
\text { a single text all the provisions } \\
\text { in force to regulate } \\
\text { immigration, particularly } \\
\text { conditions of immigration and } \\
\text { foreigners' legal status. }\end{array}$ \\
\hline
\end{tabular}

For non-EU nationals present in Italy who were already working (albeit irregularly), had proper housing and could show proof of residence by $27 / 03 / 1998$.

Entry: visa (only for migrants' origin countries for which EU legislation requires a visa) and passport are required to enter the Italian territory. Visa combined with a paper, written in the migrant's mother tongue when possible, explaining the main rights and duties for migrants in Italy (general welfare benefits such as rights to housing, language and social integration, and general rules for good social practices) are delivered by the Italian embassies in the country of origin. Visa should be accompanied by proof of financial resources for the stay, including eventual return to the country of origin. The Ministry of Foreign Affairs needs to provide and periodically update a list of countries for which EU normatives allow access to Italy, specifically the Schengen Agreement (Morocco joined the list in 1986, Egypt in 1990).

Residence: security checks, such as migrants' fingerprints and pictures, are introduced as essential conditions to grant and renew staying permits.

Duration of staying permit: three months for family visits, business and tourism; six months or for certain jobs nine months, for seasonal workers; maximum one year to study, depending on the frequency of a duly certified course of study or training, with a renewable yearly 
staying permit for the same duration for multi-year courses; two years for work and family reunification.

Migrants can ask for a staying permit within eight days of entry, to be granted for the reason expressly stated on the visa.

The staying permit for work reason is delivered only after signing a job contract. The permit is valid for nine months for seasonal contracts (maximum two contracts), for 12 months for fixed-term contracts and for 24 months for permanent contracts and self-employed workers. To get a staying permit, regardless of type of visa, foreigners need to show having proper housing.

Renewal of staying permit: at least 60 days before the expiration date. The permit is renewed for the same duration as the initial issuance. Family staying permit (Permesso di soggiorno per motivi familiari) could be delivered to those that entered Italy for family reunification with a family reunification visa.

Family reunification: 24-month permit. Eligible family members: legally married spouse aged 18 or older. Minor children, including children of the spouse, under age 18 and not married. Children over age 18 if they cannot work (handicapped or similar). Parents, economically dependent and if they have no children in the country of origin. To ask for family reunification, non-EU citizens must show having proper housing and an income at least equal to the social check (about $£ 550,000, € 284$ ). This income should be increased by half for each additional family member to be reunited. For family reunification of two or more children younger than age 14, the required income is double the social check.

Introduction of a special settlement permit to search for work (sponsor mechanism): foreign citizens are allowed to enter Italy even without an employment contract in order to establish themselves in the work environment. Precondition is that an Italian citizen or legal resident can financially support the foreigner for one year.

The Decree defines a temporary residence permit (permesso di soggiorno) and a permanent residence permit (carta di soggiorno) granted after five years of stay and with an annual income equal to the social check and proper housing.

Definition of a system of selection to facilitate entry of some categories of migrants (based on skills, origin, family ties): the quota system already written in the previous laws (1990 and 1995) becomes effective to recruit foreign workers. Special quotas are reserved for workers whose country has signed cooperation agreements (on border control, against illegal migration or drug trafficking; includes Morocco and Egypt).

Schengen measures: Ministry of the Interior implemented measures to cooperate with EU institutions to control external borders and fight undocumented immigration.

Against undocumented migration: criminalization of trafficking and smuggling of migrants. Foreigners found without documents can be expelled immediately (contrary to the previous laws); Centers of Temporary Permanence (CPT) are introduced in order to detain undocumented foreigners strictly for the time necessary for their expulsion.

Renewal of staying permit if the foreigner is abroad: cannot be granted if the foreigner stayed abroad for more than six months for yearly permits, or for a period equal to half of the permit validity for longer-validity permits.

Inscription in the Population Register: after obtaining the staying permit, foreigners should register as resident in Italy at the municipality where they live, showing their passport and staying permit.

\begin{tabular}{ll}
\hline $2000 \quad 3$ & $\begin{array}{l}\text { Directive of the Ministry of } \\
\text { Interior defining subsistence } \\
\text { criteria for entry and residence } \\
\text { of foreigners in the territory of }\end{array}$
\end{tabular}
length of the stay. 


\begin{tabular}{lll}
\hline 2000 & 388 & Financial law \\
\hline 2002 & 6 & Amnesty
\end{tabular}

Social check: Italians and foreigners over age 65 have the right to a social check if they reside in Italy and have no income.

For non-EU foreigners working irregularly in Italy at least three months before the law became effective (July 2002): dependent workers (permanent contract or minimum one-year contract), domestic and domestic care workers (minimum monthly salary $€$ 439). Employers should report the foreigner working irregularly within two months in order to get a staying permit. The full procedure is in the hands of the employers, who should guarantee the availability of proper housing for the workers.

To apply for regularization the following documents are required: photocopy of employer's ID; photocopy of worker's ID/passport; medical certificate for "needs of a care worker" (only for home-based care workers).

$20027 \quad 189 \quad$ Bossi-Fini Law: tightens the conditions of entry and residence.

are issued according to quota.

Entry visa (as in previous law): visa (only for those migrants' origin countries for which EU legislation mandates visas) and passport combined with a paper, written in the migrant's mother tongue when possible, explaining the main rights and duties for migrants in Italy (general welfare benefit, such as rights to housing and language and social integration, and general rules for good social practices) are delivered by the Italian embassies in the country of origin. Visa should be accompanied by proof of financial resources for the stay, including eventual return to the country of origin. Ministry of Foreign Affairs needs to provide and periodically update a list of countries for which access to Italy is allowed.

Residence: increased requirements to obtain a residence permit: passport, work contract and release of fingerprints.

Elimination of the special settlement permit to search for work. The reform instead links the staying permit to a specific work contract (contratto di soggiorno), so that once the work contract is terminated the foreigner must leave the country. The length of the staying permit depends on the length of the work contract.

Work contract (contratto di soggiorno), containing the employer's assurance of proper housing. The costs of the worker's return to the country of origin are paid by the employer. Introduction of a Sportello Unico (One-Stop Shop) to improve the bureaucratic procedure to receive migrants. Maximum length of the staying permit is nine months for seasonal contracts (maximum two contracts), 12 months for fixed-term contracts and 24 months for permanent contracts and self-employed workers.

Increase in years required to obtain a permanent residence permit (six instead of five).

Pension: foreigners who decide to leave Italy before retirement lose the right to take back with them the pension money they already have in the social security system unless they are going to another EU country (pension agreements between EU countries).*

Family reunification: length of the staying permit is maximum 24 months (as in the previous law). Permit renewal should be requested at least 90 days before the expiration date (as in the previous law).

Undocumented migrants: introduction of a more repressive policy towards illegal migrants through the easier use of compulsory repatriation. The period of stay in the Centers of Temporary Permanence (CPT) can be prolonged.

$20049241 \quad \begin{aligned} & \text { Legislative Decree: urgent } \\ & \text { measures on immigration }\end{aligned}$

Expulsion of undocumented migrants: once the judge's decision is validated to escort an undocumented migrant to the border, the migrant is placed in a Temporary Residence Center until final judgment. Undocumented migrants who do not exit the Italian territory after the final judgment, who do not request a staying permit or whose permit is canceled are punished with one to four years in jail for illegal entry. Staying permits that exceed the expiration date by six months have a jail penalty of six months to one year. \begin{tabular}{llll}
\hline 20071 & 3 & $\begin{array}{l}\text { Legislative Decree: execution } \\
\text { of CEE directive 2003/109/CE }\end{array}$ & $\begin{array}{l}\text { EC permits for third-country long-term residents are permanent and delivered within } 90 \text { days of the application for citizens residing in } \\
\text { Italy }\end{array}$
\end{tabular}

on status of long-term resident Categories not admitted for this permit: study, humanitarian and temporary protection, asylum seekers, short-term residents. 

one year.

$2007 \quad 1 \quad 5 \quad$ Legislative Decree: execution of CEE directive 2003/86/CE right to family reunification

European norms: family reunification is given depending on the legitimacy of family ties, by showing official documents (marriage contract, birth certificate). Applicants' staying permit (work, asylum, study, religious and family) should be at least one year.

Family members: spouse; minor children; children over age 18 who cannot live independently for health reasons (100\% invalidity); parents who do not have adequate family support in the country of origin, i.e. no children left in the country of birth; those aged 65 and older who do have children in the country of origin but these children have severe health problems and therefore cannot take care of them.

Conditions: proper housing, minimum yearly income equal to the social check.

\begin{tabular}{|c|c|c|c|c|}
\hline 2007 & 5 & 68 & $\begin{array}{l}\text { Law: discipline of short-stay } \\
\text { visas for visits of foreigners for } \\
\text { business, tourism and study }\end{array}$ & $\begin{array}{l}\text { Staying permit for visits, business, tourism and study is not necessary for a period under three months. Within eight days of arrival, entry } \\
\text { to the Italian territory should be declared to the border authority or to the police. Foreigners not respecting such rules are expelled. }\end{array}$ \\
\hline 2007 & 8 & 154 & $\begin{array}{l}\text { Legislative Decree: execution } \\
\text { of CEE directive } 2004 / 114 / \mathrm{CE} \\
\text { on conditions of admission of } \\
\text { third-country nationals for } \\
\text { purposes of study, student } \\
\text { exchange, nonremunerated } \\
\text { training or voluntary service }\end{array}$ & $\begin{array}{l}\text { Visa and residence: young people aged 20-30 coming to Italy for volunteer programs can enter the country if working for certain types of } \\
\text { promoting organizations (e.g. NGOs); a contract should be signed between the promoting organization and the local migration office. } \\
\text { The maximum duration of the staying permit granted is } 18 \text { months without possibility of renewal. }\end{array}$ \\
\hline 2008 & 1 & 17 & $\begin{array}{l}\text { Legislative Decree: execution } \\
\text { of Directive CEE } 2005 / 71 / \mathrm{CE} \\
\text { on specific procedures for } \\
\text { admitting third-country } \\
\text { nationals for purposes of } \\
\text { scientific research }\end{array}$ & $\begin{array}{l}\text { Visa and residence of highly skilled researchers: entry/stay in Italy are granted for more than three months to those who obtained a } \\
\text { Masters' degree in their country of residence (access to PhD). The Ministry of Education has a list of institutions that remain in the list } \\
\text { for five years. Research institutes can hire researchers that meet the legal requirements. Foreign researchers can be hired with a salary } \\
\text { double of the social check. } \\
\text { Family reunification for highly skilled researchers: the researcher's family member can obtain a staying permit of the same duration as } \\
\text { the researcher's. }\end{array}$ \\
\hline 2008 & 5 & 92 & $\begin{array}{l}\text { Legislative Decree: urgent } \\
\text { measures relating to public } \\
\text { safety }\end{array}$ & $\begin{array}{l}\text { Expulsion from the Italian territory of EU citizens sentenced for more than two years to jail. } \\
\text { More restrictive norm for those who try to aid undocumented migrants (e.g. offering housing). } \\
\text { Center of Temporary Permanence and Assistance (CPT) are now called Centro di Identificazione ed Espulsione (CIE). The time of } \\
\text { permanence ranges from } 30 \text { days to } 18 \text { months. Undocumented immigrants experiment a worsening of staying conditions. }\end{array}$ \\
\hline 2008 & 7 & 125 & $\begin{array}{l}\text { Application of the previous } \\
\text { Law Decree } 23 \text { May } 2008 \mathrm{n} \text {. } \\
\text { 92: urgent measures relating to } \\
\text { public safety }\end{array}$ & \\
\hline 2008 & 8 & & $\begin{array}{l}\text { Trattato italo-libico di } \\
\text { Amicizia, Partenariato e } \\
\text { Cooperazione: Italian-Libyan } \\
\text { treaty of Friendship, } \\
\text { Partnership and Cooperation }\end{array}$ & $\begin{array}{l}\text { Cooperation with maritime patrol against undocumented immigration. The Libyan government, represented by then-President Mu'ammar } \\
\text { Ghaddafi, was engaged in a major cooperation effort including border control policies and readmission agreements with the Italian } \\
\text { partner in exchange for expensive bills for Italy that included development aid in the form of infrastructure (highways, buildings) and } \\
\text { human capital (scholarships for Libyan students, border police training, etc.). }\end{array}$ \\
\hline
\end{tabular}



specified in the Law 388/2000 should apply).

$2009 \quad 101 \quad$ Amnesty

Addressed to domestic care workers working for a family for at least three months. The amnesty now addresses EU and Italian workers too. For non-EU workers the employer declaration should be done at the Local Immigration office in order to obtain a staying permit for the employee. The employer must show having a minimum annual income of $€ 20,000$. Personal IDs of employer and employee are also demanded. Proof of having employed the worker for at least three months should also be provided.

$20097 \quad 94 \quad$ Law on disposal on public security

Italian citizenship: a foreign citizen married to an Italian who is a regular Italian resident for at least two years from the marriage date or has resided abroad regularly at least three years from the marriage date can acquire Italian citizenship. Birth and marriage certificates, and proof of regular residence in Italy two years from the marriage date (population register inscription) or proof of regular residence abroad three years from the marriage date are required. The applicant also has to pay $€ 200$.

Introduction of the crime of irregular migration: a foreigner entering Italy illegally is punished with a fine (between $€ 5,000$ and 10,000 ) and immediate deportation.

\begin{tabular}{llll}
\hline 2010 & 6 & & Law Decree \\
\hline 2011 & 6 & 23 & $\begin{array}{l}\text { Law Decree: execution of CE } \\
\text { directive 2008/115/CE }\end{array}$
\end{tabular}

From 9 December 2010, it is mandatory to pass an Italian language test to get a permanent EC staying permit. \begin{tabular}{llll}
\hline 2011 & 12 & 201 & Legislative Decree: Manovra \\
& & Salva Italia, modifying art. 5
\end{tabular} Norms related to the EU directive on rights of free circulation of EU citizens.

Norm about the repatriation of undocumented non-EU citizens. 25 July 1998

$2012 \quad$ Law Decree: amnesty
workers who are waiting for issuance or renewal of their staying permit can reside and work in the Italian territory unless there are conditions that hinder the granting or the renewal of the permit. Application for a staying permit or a renewal should be done immediately after having signed the job contract in Italy

Addr employer should provide all the documents. Proof of the worker's presence in Italy before 31/12/2011 is required. In addition, $€ 1,000$ per worker should be paid. Employers must show that the worker has been employed by them for at least three months.

$2013 \quad 69 \quad$ Law Decree: urgent provisions Simplification of the procedure established by Law 91/1992 (art. 4 (2)): foreigners born in Italy can apply for citizenship even if their for economic recovery (art.33), parents or the population register did not keep the right documentation concerning their uninterrupted residence in Italy. To show their simplification of the procedure continuous residence in Italy since birth they can use any kind of official document such as school diplomas or medical certificates. for Italian-born foreigners to Municipalities should send an official communication to minors in order to inform them of the possibility of acquiring Italian citizenship. acquire citizenship This communication should be sent six months before their 18th birthday.

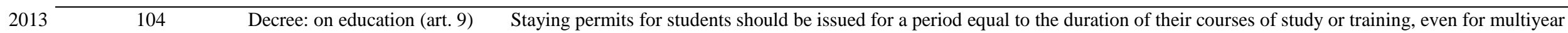
periods, in compliance with existing regulations for the certification of study and training courses, along with annual progress reports.

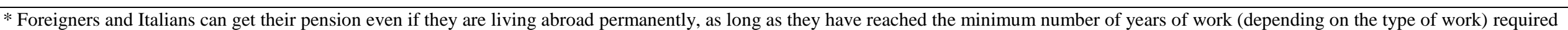
to get the pension. 


\section{Appendix 2. Amnesty}

\section{Year Eligible persons}

1982 To have entered Italy for work purposes (students not admitted).

1986 Non-EU workers present in the Italian territory when the law became effective, within three months of the start of the amnesty. Workers looking for a job, registered at the local employment office as job-seekers.

1990 Open to all foreign (non-EU and stateless) Italian residents by $31 / 12 / 1989$ regardless of the purpose of their stay.

1995 Regularization for dependent work and family reunification.

Regularization for family reunion: spouse and minor children (not parents) for family reasons within 60 days of enforcement of the law.

Regularization for irregular workers and residents: non-EU citizens present in Italy within 120 days of enforcement of the law, if the/an employer offers immediate availability of a job

\begin{tabular}{ll}
\hline 1998 & Foreigners (non-EU) present in Italy by 27/03/1998. \\
\hline 2002 & $\begin{array}{l}\text { Non-EU foreigners working irregularly in Italy for at least } \\
\text { three months before the law became effective (July 2002): } \\
\text { dependent workers (permanent contract or minimum one- } \\
\text { year contract), domestic and domestic care workers } \\
\text { (minimum monthly salary of } € \text { 439). }\end{array}$ \\
\hline 2009 & $\begin{array}{l}\text { Domestic care workers (also EU and Italian workers) } \\
\text { working for a family for at least three months. }\end{array}$ \\
& \\
\hline 2012 & $\begin{array}{l}\text { Irregular non-EU workers (full-time workers and domestic } \\
\text { workers working at least 20 hours per week). }\end{array}$
\end{tabular}

Already working in Italy (irregular workers), having proper housing and showing proof of residence in Italy at that date.

Passport or declaration of identity done in the presence of two Italians and the mayor of the city of residence; proof of presence in Italy when the regularization began.

Deposit from the employer of an amount of money equivalent to the price of a flight ticket to the foreigner's country of origin and foreign worker's medical certificate of good health.

Employers must declare irregular workers employed in their company

Foreigners must hold a passport or an officially witnessed declaration of identity.

- Passport or a declaration of identity done in the presence of two Italians and the mayor of the city of residence; proof of presence in Italy when the regularization began.

Proper housing (verified by the police) and applicant's income at least double of the social check.

\section{Duration of the amnesty}

Working foreigners who entered Italy before $31 / 12 / 1981$

Within three months of the law becoming effective (January 1986). The period was subsequently prolonged until 31/12/1987.

For those foreigners present in Italy by 31/12/1989: 180 days (from the moment the law became effective)

60 days for family reunification and 120 days for dependent work.

Later on, a new decree stated that regularization should be done by $31 / 3 / 1996$.

- Migrants who can show having worked in the previous four months.

Migrants registered in the local placing/employment office's list of job-seekers.

Employers must report the

For those present in Italy by 27/03/1998 must guarantee the availability of proper housing for the workers. Documents: photocopy of employer's ID; photocopy of worker's ID/passport; medical certificate for "needs of a care worker" (only for home-based care workers).

\section{For non-EU workers the employer declaration should be done at the local} immigration office, showing a minimum annual income of $€ 20,000$. Documents: personal IDs of employer and employee; proof of having employed the worker for at least three months.

Employer must prove the worker's presence in Italy before 31/12/2011. Employer pays $€ 1,000$ per worker. Employers should show that an employee has worked for hem for at least three months.
Employers should declare the presence September .

\section{From 15 September to 15 October:}

period to ask for regularization

(employers) of illegal workers between 1 and 30 


\section{Appendix 3. Entry of labor migrants*}

Year Documentation/evidence required for Moroccans and Egyptians to enter Treatment of undocumented non-EU migrants Italy

1931 Declaration of presence to the police within three days of arrival. Employer's

declaration to the police within five days of the beginning and end of the

contract.

1963 Visa and work authorization (excluding Italian residents and those who entered

Structural Decreasing

the country for reasons other than work but are already active on the labor

market).

1986 Visa for work reasons.

Work authorization issued by the labor offices before the visa; lasts two years

1990 Passport, stamped, recorded at the border and sent to the Italian Ministry of

Interior.

Visa specifying reason for entry, duration of stay and number of entries.

Proof of financial resources (goods and services in Italy or a guarantee).

\begin{tabular}{|c|c|c|c|c|}
\hline 1995 & Visa extended to seasonal workers. & & Marginal & Decreasing \\
\hline 1998 & $\begin{array}{l}\text { Passport. } \\
\text { Visa combined with a paper, written in the migrant's mother tongue when } \\
\text { possible, explaining the main rights and duties for migrants in Italy. } \\
\text { Proof of financial resources for the stay, including eventual return to the } \\
\text { country of origin. }\end{array}$ & $\begin{array}{l}\text { Possibility to immediately expel foreigners without documents. } \\
\text { Introduction of Center of Temporary Permanence (CPT) to detain } \\
\text { undocumented foreigners waiting for expulsion. }\end{array}$ & Structural & Decreasing \\
\hline 2002 & $\begin{array}{l}\text { Passport. } \\
\text { Visa combined with a paper, written in the migrant's mother tongue when } \\
\text { possible, explaining the main rights and duties for migrants in Italy. } \\
\text { Proof of financial resources for the stay, including eventual return to the } \\
\text { country of origin. }\end{array}$ & $\begin{array}{l}\text { Introduction of a more repressive policy towards illegal migrants through the } \\
\text { easier use of compulsory repatriation. } \\
\text { Possibility to prolong the period of stay at Centers of Temporary Permanence } \\
\text { (CPT). }\end{array}$ & Structural & Decreasing \\
\hline 2004 & & $\begin{array}{l}\text { Once the judge's decision is validated to escort an undocumented migrant to } \\
\text { the border, the migrant is placed in a Center of Temporary Permanence (CPT) } \\
\text { until final judgment. } \\
\text { Undocumented migrants who do not leave the Italian territory after the final } \\
\text { judgment are punished with one to four years in jail. } \\
\text { Staying permits that exceed the expiration date by six months have a jail } \\
\text { penalty of six months to one year. }\end{array}$ & Structural & Decreasing \\
\hline 2007 & & Cooperation with maritime patrol to fight against undocumented migrants. & & \\
\hline
\end{tabular}


Centers of Temporary Permanence and Assistance (CPT) are now called

Centro di Identificazione ed Espulsione (CIE). Time of permanence ranges

from 30 days to 18 months. Undocumented immigrants experiment a

worsening of staying conditions.

2011

Repatriation of undocumented migrants.

Structural Decreasing

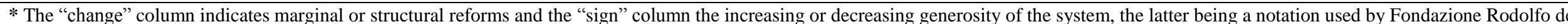
Benedetti (Inventory of migration policies (1990-2005), available at: http://www.frdb.org/topic/data-sources/doc pk/11028, accessed June 20, 2015). 
Appendix 4. Residence permit for labor migrants*

Year Documentation/evidence required for Moroccans Maximum duration of stay and Egyptians to obtain residence permit

\section{Documentation/evidence requirement}

to renew residence permi
Maximum

renewal

duration

Proof of new/renewed job contract.

Confirmed job contract.

Document showing that the migrant or

one of his/her family members has a minimum income equal to the social pension and proper housing.

stay. Exception: unlimited for those married to an Italian citizen an residents for over three years.

Not renewable for seasonal workers.

1995
fingerprints and pictures as essential conditions to allow the staying permit.

Six months for seasonal workers.

Nine months for seasonal contracts (maximum two contracts).

12 months for fixed-term contracts.

Requesting staying permit within eight days of entry. Staying permit for work reasons is given only after signing a job contract.

24 months for permanent contracts and self-employed workers.
Introduction of security checks, such as migrants' fingerprints and pictures as essential conditions to renew staying permit.

Applying for renewal of staying permit at least 60 days before the expiration date.

Document that shows proper housing.

Five years of residence required to obtain permanent residence permit.

\begin{tabular}{ll}
\hline 2002 & Passport. \\
& Work contract containing employer's assurance of
\end{tabular}

proper housing.

Release of fingerprints.

Six years of residence required to obtain And permanent residence permit.

2007 To not reside outside Italy for longer than six years or outside EU member states for more than one year.

2010 An Italian language test to obtain a permanent EC staying permit is introduced.

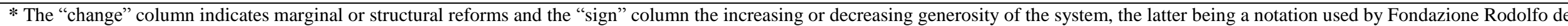
Benedetti (Inventory of migration policies (1990-2005), available at: http://www.frdb.org/topic/data-sources/doc_pk/11028, accessed June 20, 2015). 
Appendix 5. Entry through family reunification*

Year Eligible family members Documentation/evidence required for Moroccan
and Egyptian followers to enter Italy
Max. Documentation/

Stay evidence

requirement to

renew residence

permit

The reason to access Italy should not be to look for a job (although working is permitted can work after one year of regular stay).

A confirmed job

contract (for the

worker)

Maximum

renewal

duration

Change

Sign

Minor non-married children (economically dependent)

Parents (economically dependent)

1995 Spouse.

Minor children.

One year of regular entry and residence for the person 2 years

applying for family reunification.

Proper housing.

Monthly income of at least double the social check

for reunifying with spouse and two children (amount

doubled for every two additional children).

1998 Spouse legally married and aged 18 or older.

Proper housing.

Minor children, including children of the spouse, under age 18 and not married.

Children over age 18 if they cannot work (handicapped or similar).

An income at least equal to the social check for reunifying with one person (income increased by half for each additional family member, and should be double the social check for two or more children younger than 14).

Parents, economically dependent and with no children in the country of origin.

\begin{tabular}{|c|c|c|c|c|c|c|}
\hline 2002 & & & $\begin{array}{l}24 \\
\text { months }\end{array}$ & $\begin{array}{l}\text { Request permit } \\
\text { renewal at least } \\
90 \text { days before the } \\
\text { expiration date. }\end{array}$ & Structural & $\begin{array}{l}\text { Neither } \\
\text { decreasing nor } \\
\text { increasing (no } \\
\text { major } \\
\text { changes) }\end{array}$ \\
\hline 2007 & $\begin{array}{l}\text { Spouse. } \\
\text { Minor children. } \\
\text { Children over } 18 \text { age who cannot live independently } \\
\text { due to health reasons ( } 100 \% \text { invalidity). } \\
\text { Parents who do not have adequate family support in the } \\
\text { country of origin, i.e. no children left in the country of } \\
\text { birth or those aged } 65 \text { and older who do have children } \\
\text { in the country of origin but these children have severe } \\
\text { health problems and therefore cannot take care of them. }\end{array}$ & $\begin{array}{l}\text { Official documents (marriage contract, birth } \\
\text { certificate) showing the legitimacy of family ties. } \\
\text { Proper housing. } \\
\text { Minimum yearly income equal to the social check. } \\
\text { Staying permit (work, asylum, studies, religion, } \\
\text { family) of at least one year for the person applying } \\
\text { for family reunification. }\end{array}$ & & & Marginal & Decreasing \\
\hline
\end{tabular}

24

renewal at least

90 days before the

expiration date.
Structural Increasing

(family

reunification

introduced for

the first time)

Can be

Marginal

Decreasing

the same

duration as

the initial

one.

Structural Decreasing

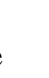

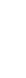


* The "change" column indicates marginal or structural reforms and the "sign" column the increasing or decreasing generosity of the system, the latter being a notation used by Fondazione Rodolfo de Benedetti (Inventory of migration policies (1990-2005), available at: http://www.frdb.org/topic/data-sources/doc pk/11028, accessed June 20, 2015). 
1912 By birth (Ius sanguinis): the children of an Italian male citizen

Children of an Italian female citizen if the father is unknown, if the father is stateless or if they do not take the citizenship of the non-Italian father in accordance with his country's legislation.

A foreign citizen born in Italy or whose parents have resided in Italy for 10 years and: (a) he does military service in Italy; (b) s/he works for the Italian government; (c) at the age of $21 \mathrm{~s} / \mathrm{he}$ is an Italian resident and applies for Italian citizenship by his/her 22nd birthday; (d) s/he has been an Italian resident for at least 10 years and doesn't choose to keep his/her foreign citizenship by his/her 22nd birthday.

Others: having served the Italian state for three years, in Italy or abroad; having resided in Italy for at least five years; having resided in Italy for two years and having rendered outstanding service to Italy or having contracted marriage with an Italian citizen; after six months of residence, for those who could have become Italian citizens but failed to expressly apply for citizenship timely.

1983 By marriage: any person who is a regular Italian resident at least six months from the marriage date or has resided abroad regularly at least three years from the marriage date.

Children of an Italian man or woman (citizenship by mother or father transmission).

1992 Italian-born foreigners: legal Italian residents until the age of 18 can apply within one year of turning 18

By marriage to an Italian if regular Italian resident at least six months from the marriage date or residing abroad regularly at least three years from the marriage date.

By residence: EU citizens if residing in Italy at least four years; stateless citizens if residing in Italy at least five years; non-EU citizens if residing in Italy at least 10 years.

Proof of regular residence in Italy six months from the marriage date

(population register inscription) or proof of regular residence abroad three

years from the marriage date.

Birth certificate.

\section{Birth certificate.}

Proof of residence in Italy (population register inscription).

Birth certificate.

Marriage certificate

Proof of regular residence in Italy six months from the marriage date

(population register inscription) or proof of regular residence abroad three years from the marriage date.

Birth certificate.

Proof of residence.

Income statement of the applicant or the supporting family member, with a

minimum yearly income of $€ 8300$ for the three years prior to the

citizenship application date.

\section{By marriage: any foreigner married to an Italian, who is a regular Italian resident for at least two years from the marriage date or has resided abroad regularly at leas three years from the marriage date.}

\section{Birth certificate and marriage certificate.}

Proof of regular residence in Italy two years from the marriage date

(population register inscription) or proof of regular residence abroad three years from the marriage date.

200 tax. 


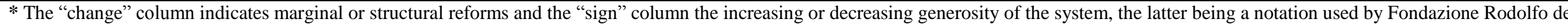
Benedetti (Inventory of migration policies (1990-2005), available at: http://www.frdb.org/topic/data-sources/doc_pk/11028, accessed June 20, 2015). 